\title{
KARAKTERISTIK BATUAN INDUK HIDROKARBON FORMASI CIBULAKAN DI DAERAH PALIMANAN, CIREBON, JAWA BARAT
}

HYDROCARBON HOST ROCK CHARACTERISTICS OF CIBULAKAN FORMATION AT PALIMANAN AREA, CIREBON, WEST JAVA

\author{
Praptisih dan Kamtono \\ Puslit Geoteknologi LIPI \\ Jalan Sangkuriang Komplek LIPI, Bandung \\ praptie3103@yahoo.com
}

diterima : 17 Februari 2014

direvisi : 21 April 2014

disetujui : 20 April 2014

\section{ABSTRAK}

Penelitan batuan induk hidrokarbon yang dilakukan pada Formasi Cibulakan di daerah Palimanan, Cirebon bertujuan untuk memperoleh data permukaan endapan klastik berbutir halus serta karakteristik litofasies yang diduga sebagai batuan induk hidrokarbon. Metode yang dipakai adalah penelitian lapangan dan laboratorium. Penelitian lapangan meliputi pengamatan stratigrafi detil dan pengambilan conto batuan, sedang analisis laboratorium terdiri dari analisis kandungan Total Organic Carbon dan analisis Pirolisis Rock Eval. Hasil analisis Total Organic Carbon terhadap 17 conto batulempung dan batulanau yang diambil dari Formasi Cibulakan menunjukkan nilai berkisar 0,27-4,43\%, dan umumnya mempunyai potensi membentuk hidrokarbon dalam katagori rendah hingga sangat baik. Pirolisis Rock Eval dilakukan terhadap 9 conto yang berpotensi membentuk hidrokarbon dan memperlihatkan nilai $\mathrm{T}_{\max }$ sebesar $331-557^{\circ} \mathrm{C}$. Nilai yang menunjukkan tingkat kematangan termal sebanyak 6 conto dinyatakan matang hingga pasca matang dengan nilai $T_{\max }$ berkisar $445-557^{\circ} \mathrm{C}$, sedang 3 conto lainnya belum matang dengan nilai $T_{\max }$ sebesar $331-362^{\circ} \mathrm{C}$. Nilai Hydrogen Index berkisar 3-338 mg Hydrocarbon/g Total Organic Carbon, dan berada dalam fasies BC, CD dan D. Batuan induk tersebut dapat menghasilkan minyak dalam kuantitas sedang dan gas dalam kuantitas kecil. Potensi hidrokarbon di daerah penelitian menunjukkan kategori kekayaan material organik rendah hingga sangat baik, dengan kerogen termasuk tipe II dan III. Kualitas batuan sumber berdasarkan nilai Hydrogen Index termasuk dalam kategori gas prone dan oil prone.

Kata Kunci : batulempung, batuan induk, Formasi Cibulakan, hidrokarbon, Total Organic Carbon (TOC).

\section{ABSTRACT}

Study of hydrocarbon that was carried out on the Cibulakan Formation in the area of Palimanan, Cirebon aims to obtain surface data of fine-grained clastic sediments and lihtofacies characteristics that estimated as hydrocarbon source rock. The methods used in this research are field study and laboratory analyses. Field research includes detailed stratigraphic observations and taking some rock samples, while laboratory analysis consists of analyzing the content of TOC and Rock Eval pyrolysis. Results of TOC analysis of the 17 samples claystone and siltstone showed the values ranging from of 0.27 to $4.43 \%$ and generally have potential to generate hydrocarbon from the category low to very good. RockEval Pyrolysis performed on 9 samples that potential to generate hydrocarbons and shows value of $T_{\max }$ of $331^{\circ}$ to $557^{\circ} \mathrm{C}$. Value that indicates the level of thermal maturity as much as 6 samples expressed mature to post mature with $T_{\max }$ values ranging from 445 to $557^{\circ} \mathrm{C}$, while the other 3 samples with immature $T_{\max }$ values of 331 to $362^{\circ} \mathrm{C}$. HI values

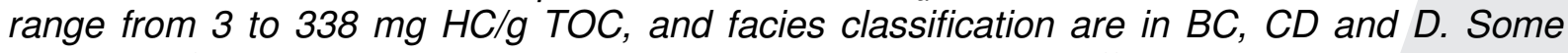
samples of source rock in this study area can generate oil in sufficient quantity, and gas in small quantity. The hydrocarbon source rock potential level in the investigation area shows 
poor to very good organic richness, and kerogen is included into type II and III. The source rock quality on the hydrogen Index $(\mathrm{HI})$ value tends to be gas prone and oil prone.

Keywords : Cibulakan Formation, claystone, hydrocarbon, source rock, TOC.

\section{PENDAHULUAN}

Dalam sistem minyak bumi (Petroleum system) terdapat empat unsur utama yang berkaitan dengan terdapatnya hidrokarbon dalam suatu cekungan. Unsur penting tersebut adalah terdapatnya batuan induk (source rock), reservoir, lapisan penutup (seal) dan perangkap (trap). Karakteristik umum batuan induk adalah batuan sedimen klastik berbutir halus umumnya berwarna gelap karena mengandung material organik, yang dalam kedudukannya di alam telah dan/atau sedang menghasilkan hidrokarbon yang dapat terakumulasi menjadi minyak atau gas (Brooks, 1987, op.cit Einsele, 2000).

Studi geokimia batuan induk akan memberikan informasi prosentase kandungan material organiknya tiap satuan volume, tingkat kematangan serta kemampuan batuan induk untuk dapat melepaskan kandungan hidrokarbon, sehingga gambaran potensi batuan induk dapat diketahui (Waples, 1985). Salah satu indikasi adanya batuan induk adalah rembesan gas atau minyak di permukaan.

Di Jawa Barat wilayah daratan sebagian besar rembesan minyak atau gas secara fisiografi berada pada zona Antiklinorium Bogor yang tertutup oleh endapan volkanik Kuarter. Dari fakta ini, secara stratigrafi diduga di bawah batuan volkanik Kuarter terdapat batuan yang mempunyai karakteristik sebagai batuan induk. Dalam tulisan ini disajikan hasil studi geokimia batuan yang diduga sebagai batuan induk yang sebagian besar conto diambil dari area pabrik semen yang dikelola oleh PT Indocement.

Tujuan utama dari studi ini adalah untuk menguji suatu dugaan bahwa batuan yang dapat bertindak sebagai batuan induk adalah batuan dari Formasi Cibulakan. Beberapa conto singkapan terpilih dianalisis geokimia yang meliputi kandungan material organik dan analisis pirolisis rock eval.

\section{METODOLOGI}

Dalam studi batuan induk, diawali dengan penelusuran pustaka mengenai cekungan-cekungan sedimen yang telah terbukti mengandung hidrokarbon. Kemudian dilakukan pengamatan karakteristik dan potensi batuan induk, pengambilan conto batuan di permukaan yang selanjutnya dianalisis kandungan Total Organic Carbon (TOC) dan analisis pirolisis Rock Eval. Analisis ini untuk mengetahui indeks produksi $(\mathrm{PI})$, Indeks Hidrogen $(\mathrm{HI})$ dan temperatur maksimum pembentukan hidrokarbon dari kerogen.

\section{GEOLOGI}

Penelitian geologi detil di kompleks Gunung Kromong telah dilakukan oleh Pringgoprawiro dkk., 1977 (Gambar 1), ditujukan untuk mengetahui kandungan fosil foraminifera yang terdapat di daerah tersebut dan hasilnya menjadi dasar penyusunan biostratigrafi. Batuan tertua yang tersingkap di daerah Kromong adalah Formasi Cibulakan terdiri dari batugamping di bagian bawah dan ditutupi oleh sedimen lempung bersisipan lapisan-lapisan tipis batugamping di bagian atas. Berdasarkan fosil foraminifera besar yang terdapat dalam batuan gamping, Formasi Cibulakan ditafsirkan berumur Miosen Tengah (Pringgoprawiro dkk., 1977).

Selaras di atas Formasi Cibulakan diendapkan Formasi Parigi disusun oleh lapisan batugamping berwarna abu-abu dan bersifat keras, berumur Miosen Atas berdasarkan fosil foraminifera. Di atas Formasi Parigi diendapkan Formasi Cisubuh yang disusun terutama oleh batulempung bersisipan batupasir berlapis tipis. Batulempung Formasi Cisubuh ini mengandung banyak foraminifera kecil yang berumur Mio-Pliosen (Pringgoprawiro dkk., 1977). Formasi Cisubuh secara tidak selaras ditutupi oleh batuan-batuan volkanik muda berumur Plistosen. 


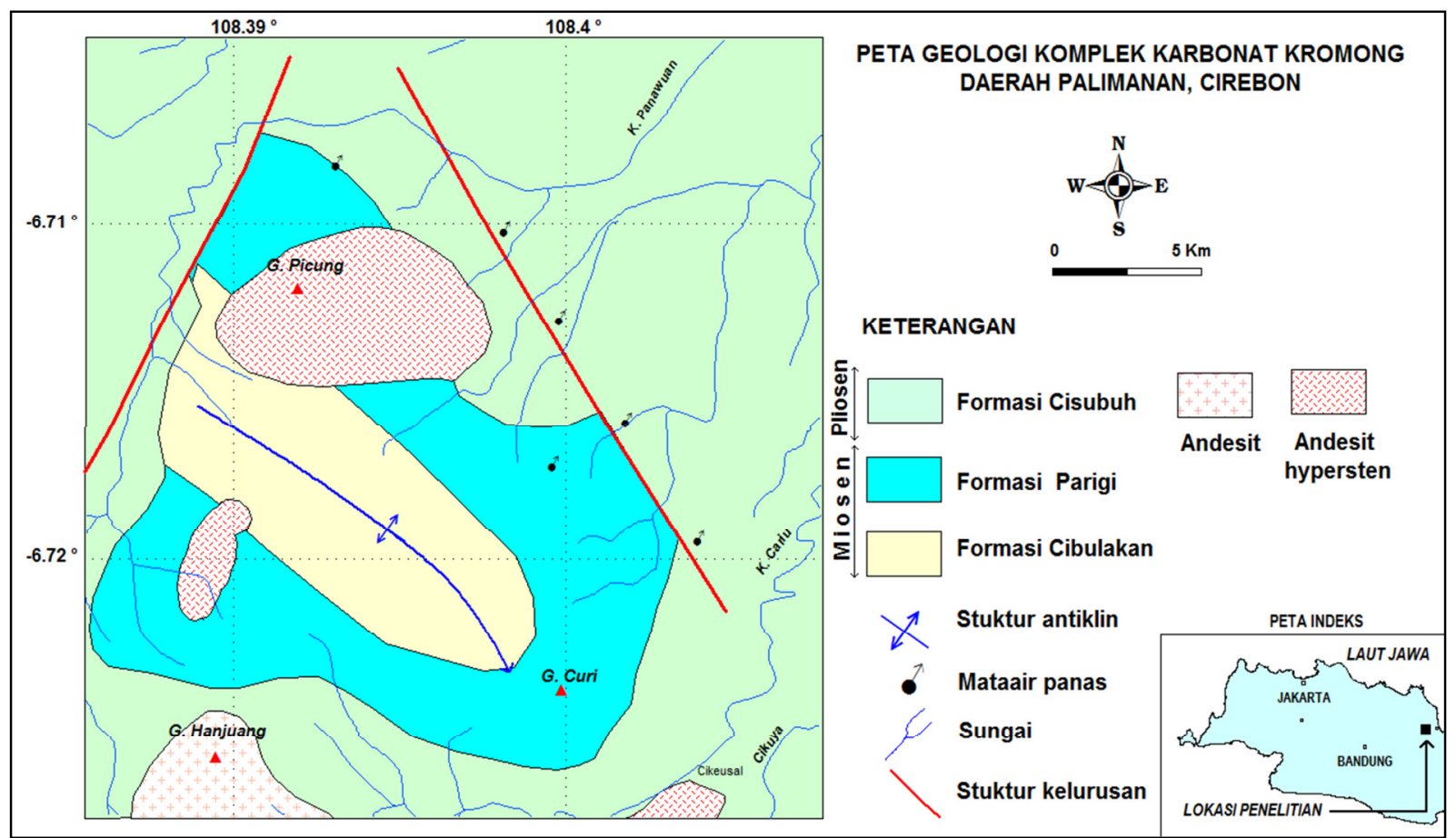

Gambar 1. Peta Geologi Komplek Karbonat Kromong, daerah Palimanan Cirebon (Pringgoprawiro, dkk., 1977).

Batuan karbonat di Kompleks Kromong diterobos oleh andesit dan dasit pada Plio-Plistosen yang mengakibatkan terjadinya proses rekristalisasi pada beberapa bagian dari batuan karbonat Formasi Cibulakan dan Formasi Parigi. Struktur geologi yang terdapat di daerah penelitian terdiri dari antiklin dan beberapa kelurusan (Gambar 1).

\section{Hasil Pengamatan Lapangan}

Penelitian dilakukan di daerah Palimanan Cirebon (Praptisih, dkk, 2013). Pengamatan singkapan batuan dilakukan pada Formasi Cibulakan di lokasi-lokasi terpilih. Lokasi pengamatan dan pengambilan conto batuan dituangkan dalam Gambar 2.

$\mathrm{Di}$ lokasi bekas tambang batugamping dijumpai rembesan minyak yang tercampur dengan air dan aspal yang berwarna hitam (Gambar 3A). Lokasi
Rembesan terdapat di batas antara Formasi Parigi dan Formasi Cibulakan. Batugamping Formasi Parigi dengan ketebalan sekitar 56 meter, bagian bawah ditempati batugamping packstone, berwarna abu-abu, mengandung branching coral, moluska, worm tube, red algae, juga didapatkan lensa-lensa batulempung karbonan yang berwarna hitam (Gambar 3B), di atasnya diendapkan batugamping setebal $1,5 \mathrm{~m}$ yang kaya oleh branching coral. Batugamping berwarna abu-abu yang banyak mengandung fosil cycloclypeus annulatus diendapkan diatasnya. Batugamping packstone yang mengandung pecahan branching coral, worm tube, dan moluska dengan sisipan serpih abu-abu setebal $3 \mathrm{~m}$. Paling atas diendapkan batugamping putih kekuningan hingga kecoklatan dengan tebal $40 \mathrm{~m}$ (Conto P01 A-F). 


\section{MAKALAH ILMIAH}

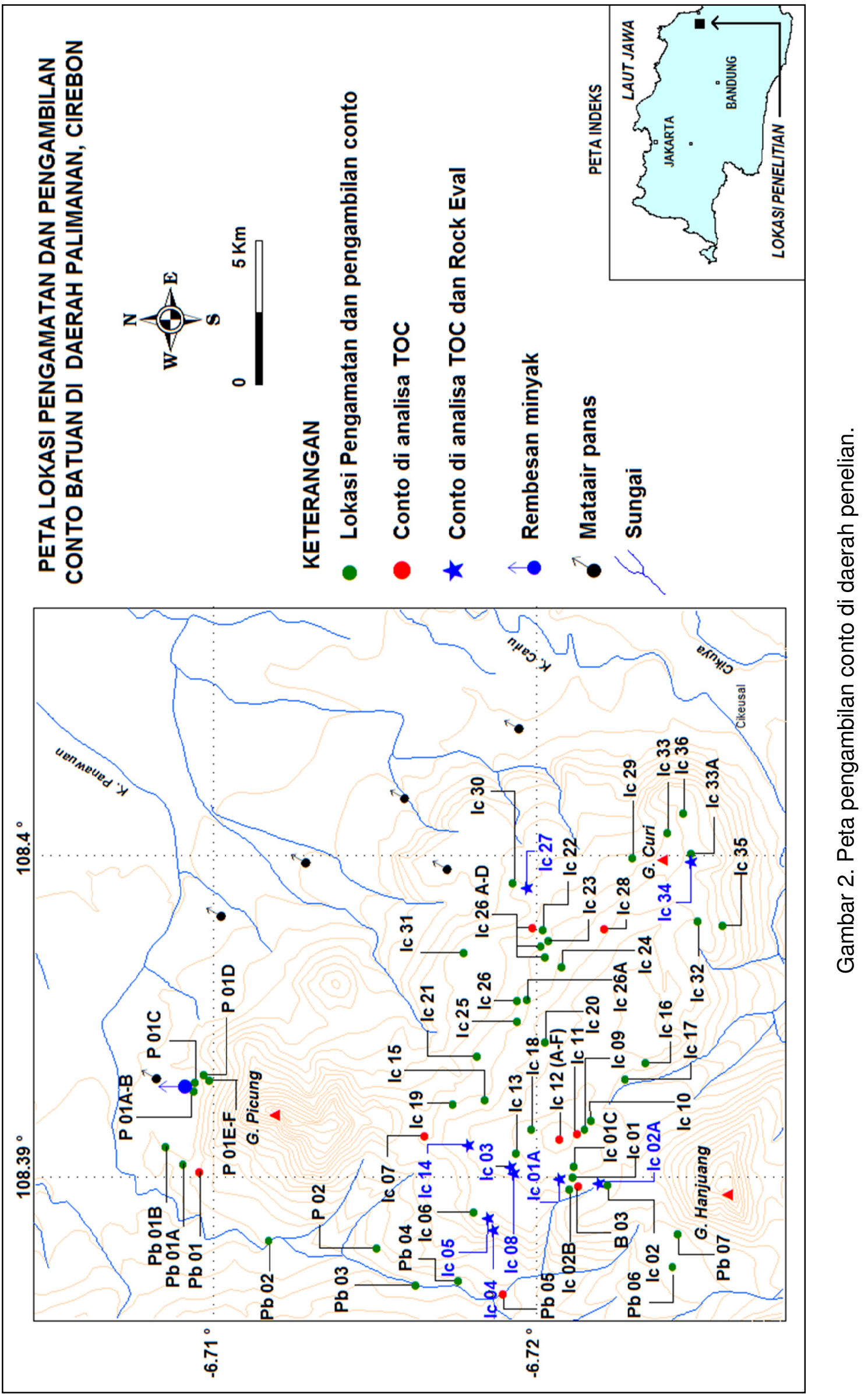




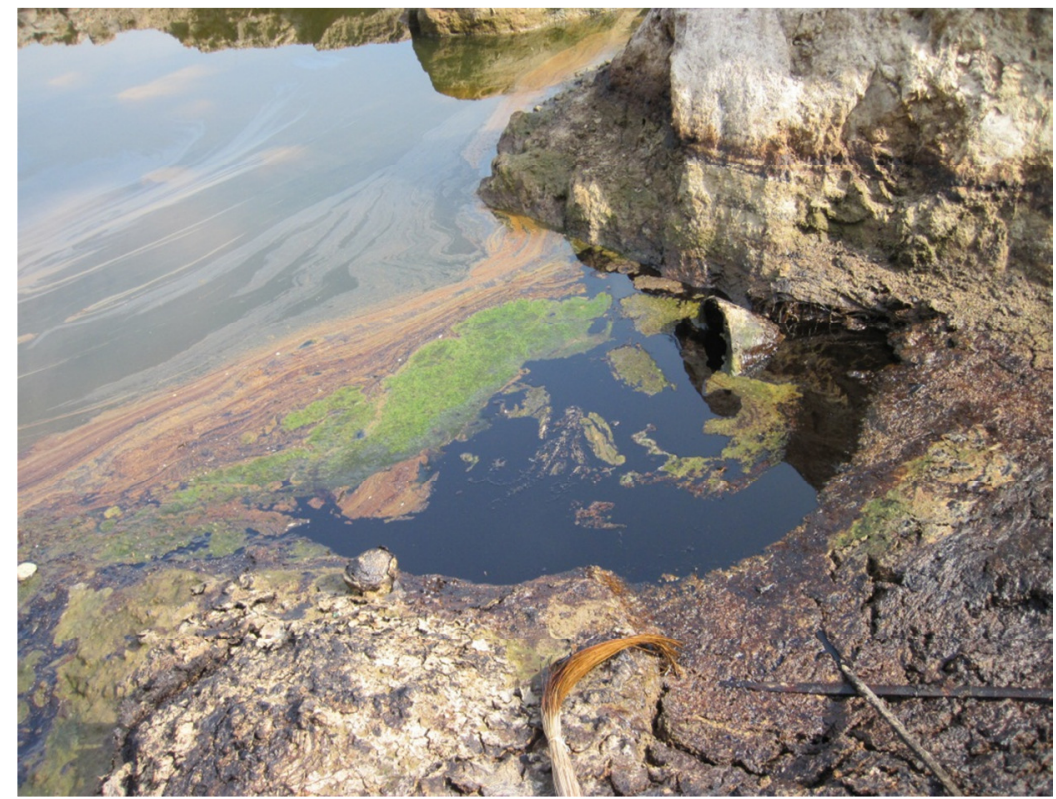

Gambar 3A. Rembasan minyak tercampur dengan air dan aspal berwarna hitam di lokasi Palimanan Barat.

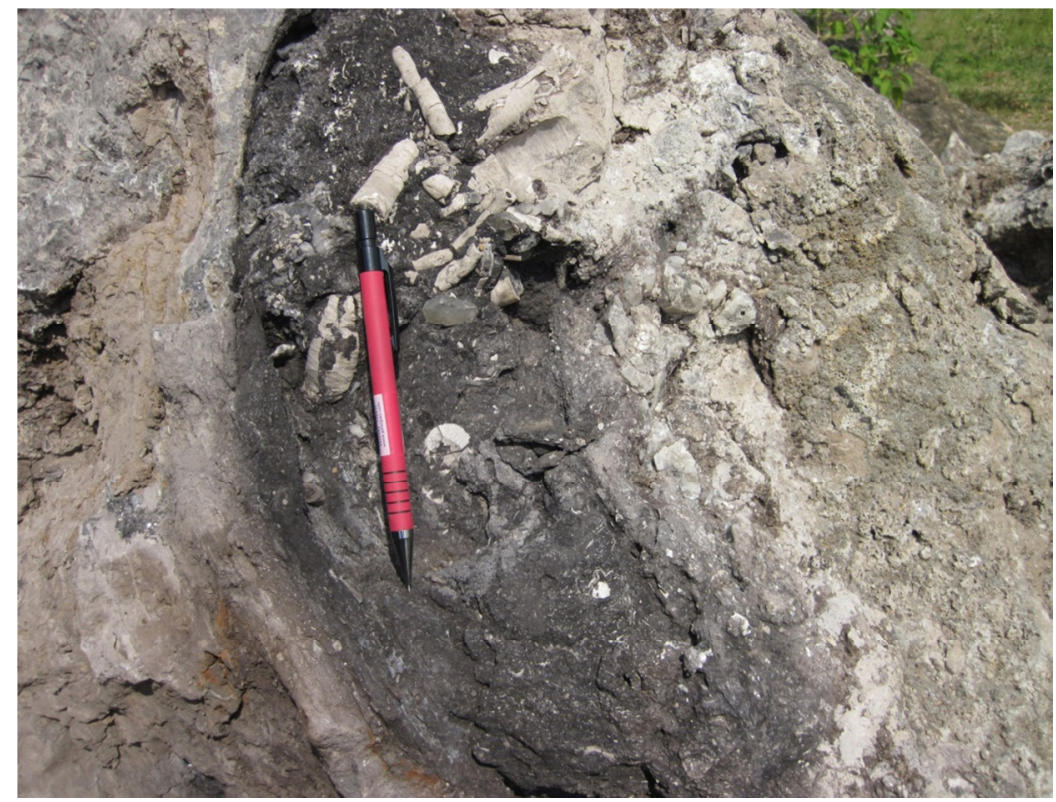

Gambar 3B. Lensa-lensa batulempung karbonan berwarna hitam pada batugamping Di lokasi Palimanan Barat.

Singkapan batulempung, berwarna abu-abu hingga kehitaman dengan ketebalan $3 \mathrm{~m}$. Terdapat lensa-lensa batugamping (Gambar $4 \mathrm{~A}$ ), berwarna putih kekuningan hingga kecoklatan, banyak mengandung fosil koral bercabang. Pada lokasi PB 01A dijumpai singkapan batupasir setebal $4 \mathrm{~m}$, berwarna kehijauan mengandung glaukonit (Gambar 4B), di atasnya diendapkan batulempung berwarna kehitaman dan menyerpih.
Singkapan dengan tebal $4 \mathrm{~m}$ didapatkan pada lokasi PB 01B disusun oleh paling bawah batugamping berwarna abu-abu mengandung moluska. Di atasnya diendapkan batupasir, abu-abu kehijauan dengan nodul-nodul batulempung, sebagian berwarna kemerahan karena mengalami oksidasi. Kemudian diendapkan batulempung berwarna abu-abu hingga kecoklatan. 


\section{MAKALAH ILMIAH}

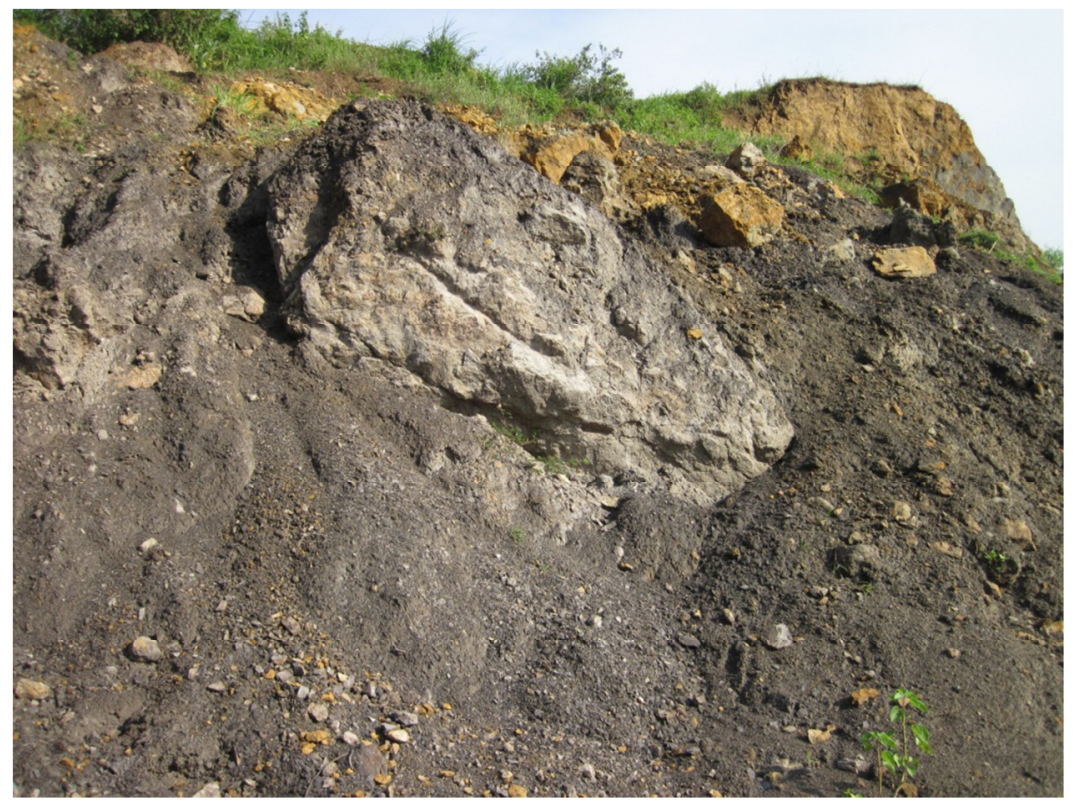

Gambar 4A. Lensa batugamping pada singkapan batulempung pada lokasi PB 01.

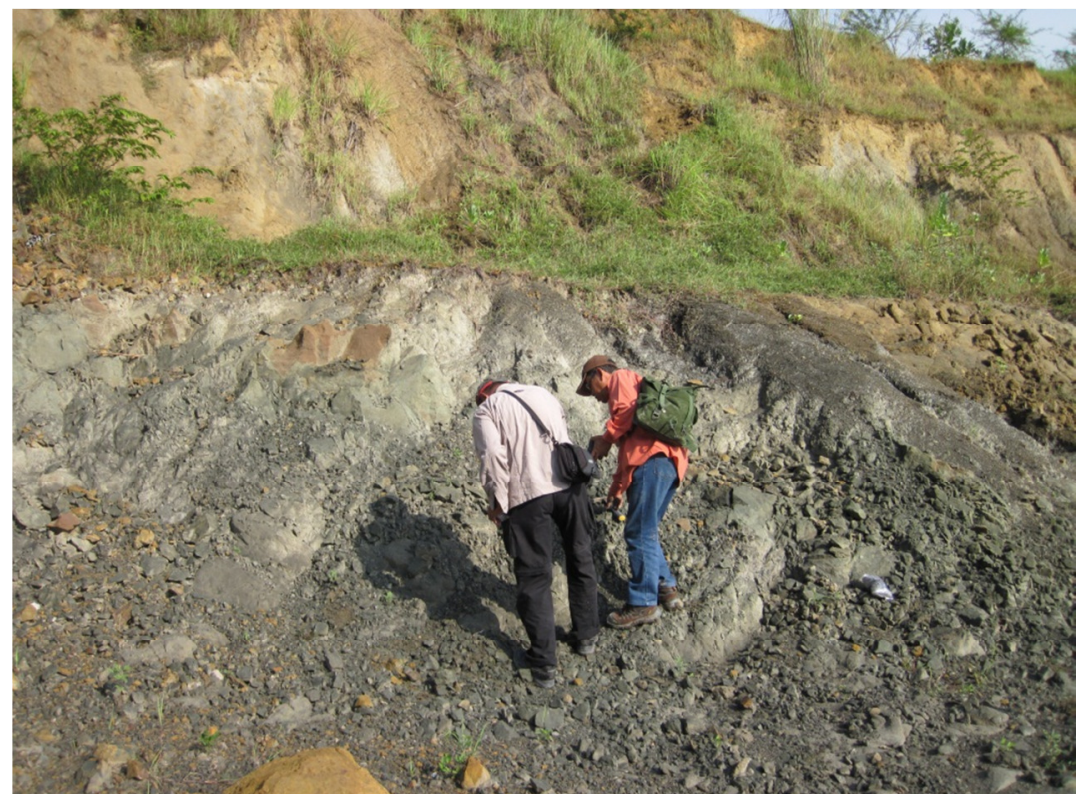

Gambar 4B. Singkapan batupasir berwarna kehijauan mengandung glaukonit di lokasi PB 01.

Dijumpai singkapan yang terdiri dari batulempung dengan nodul-nodul batupasir, diatasnya didapatkan batupasir yang mengandung pirit (Gambar 5), uraturat kuarsa kemudian diendapkan batulempung berwarna abu-abu, menyerpih. Singkapan ini di dapatkan pada lokasi PB 02 dan PB 03. Pada lokasi PB 04 dijumpai mata air panas yang mengandung belerang. Pada lokasi PB 05-PB 07 dijumpai singkapan yang merupakan batas antara Formasi Parigi dan Formasi Cibulakan yang terdiri dari batugamping berwarna putih kekuningan dengan lensalensa batulempung yang berwarna abu-abu hingga kehitaman (Gambar 6A). 


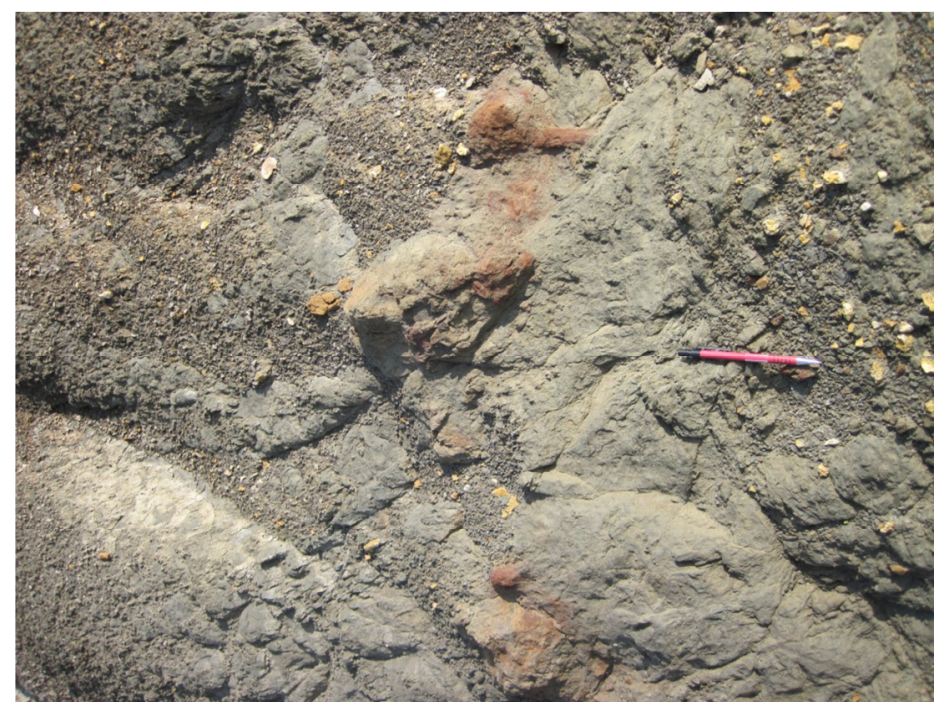

Gambar 5. Singkapan batupasir yang mengandung pirit di lokasi Sungai Penawaran.

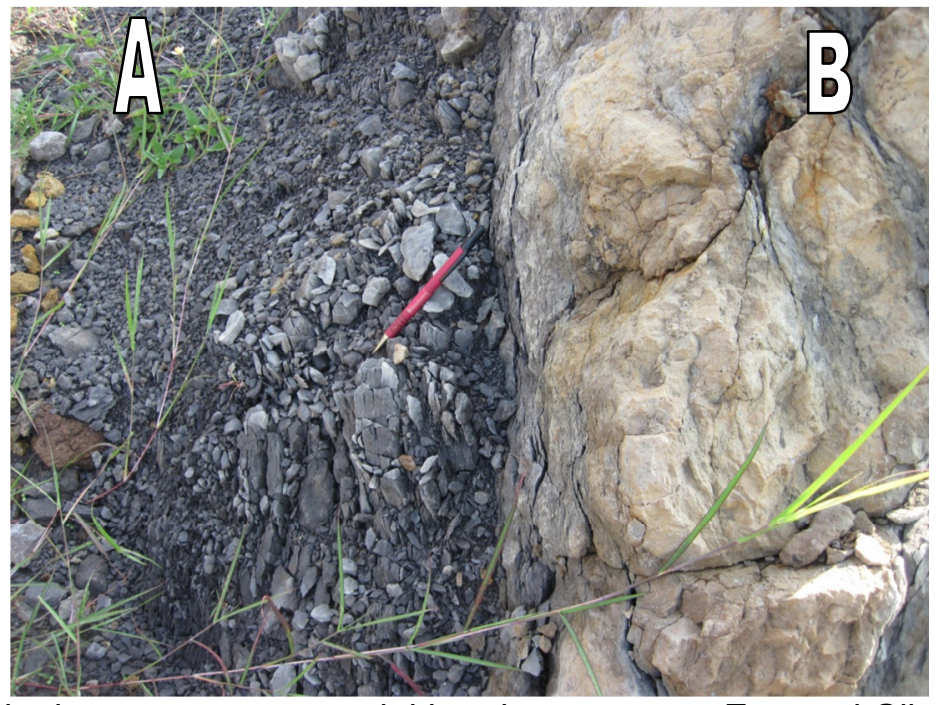

Gambar 6A. Singkapan yang menunjukkan batas antara Formasi Cibulakan (A) dan Formasi Parigi (B) di lokasi Sungai Penawaran.

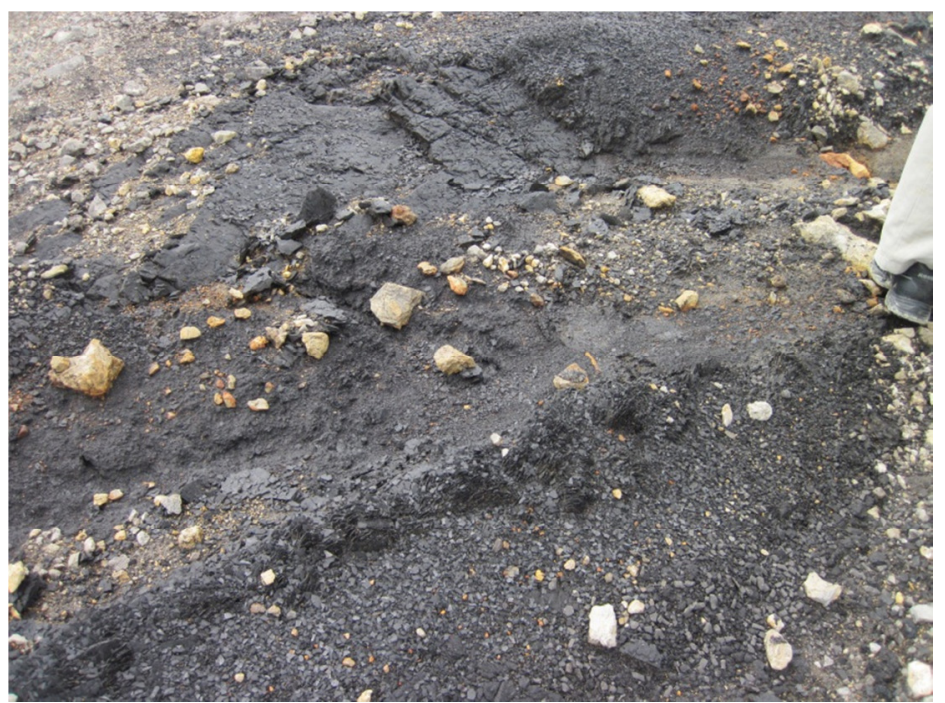

Gambar 6B. Singkapan batulempung berwarna hitam yang berbau minyak di lokasi IC 01. 


\section{MAKALAH ILMIAH}

Terdapat lensa batulempung berwarna hitam (IC 01) yang berbau minyak di dalam lapisan batugamping (Gambar 6B). Batugamping berwarna abuabu berupa packstone, mengandung worm tube, potongan koral dan moluska. Pada lokasi ini diambil conto (IC 01 A) untuk analisis TOC.

Singkapan batugamping berwarna abu-abu (IC 02), mengandung branching coral yang melimpah dengan lensa-lensa perselingan antara batulempung dan batupasir. Batulempung berwarna hitam, karbonan dengan tebal lapisan antara 0,1$1 \mathrm{~cm}$. Batupasir berwarna abu-abu terang, dengan ukuran halus, tebal lapisan berkisar $5-10 \mathrm{~cm}$. Pada lokasi ini diambil conto batulempung (IC $02 \mathrm{~A}$ ) untuk analisis TOC.

Pada lokasi IC 03-IC 08 dijumpai singkapan yang terdiri dari perselingan antara batugamping dan batupasir dengan sisipan batulempung. Batugamping berwarna abu-abu kekuningan hingga kecoklatan, mengandung platy coral dan branching coral. Batulempung berwarna hitam, karbonan dengan tebal lapisan 30$40 \mathrm{~cm}$ (Gambar 7A). Batupasir berwarna abu-abu terang, dengan ukuran halus, tebal lapisan berkisar $1-5 \mathrm{~cm}$. Pada lokasi ini diambil 5 conto batulempung (IC 03, IC 04, IC 05, IC 07, IC 08) untuk analisis TOC (Gambar 7B).

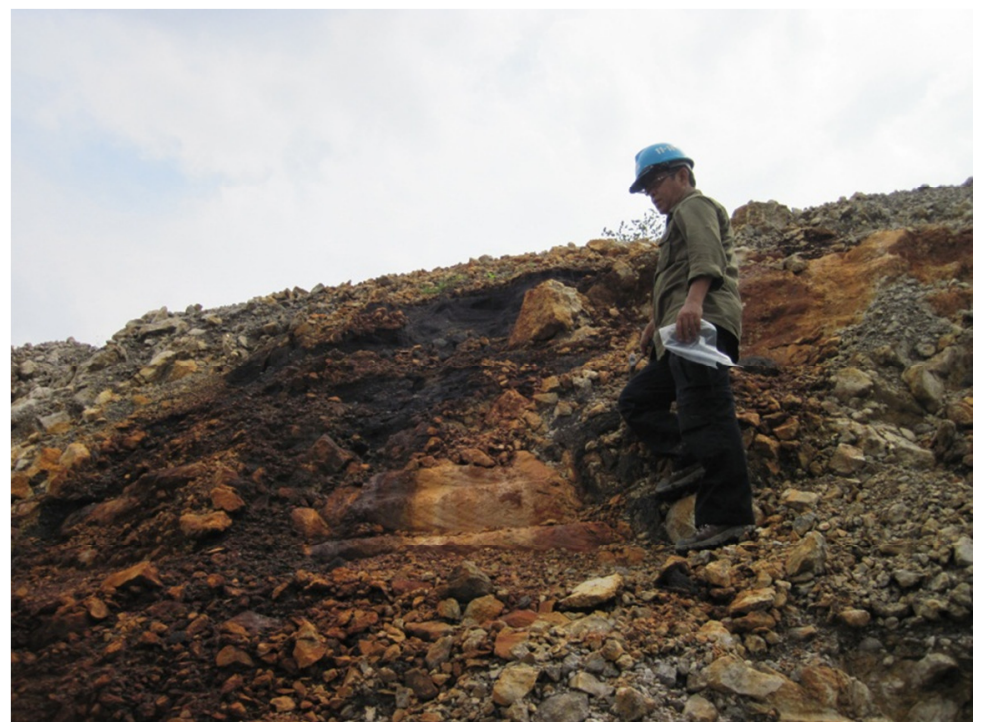

Gambar 7A. Batulempung berwarna hitam, karbonan pada lokasi IC 04.

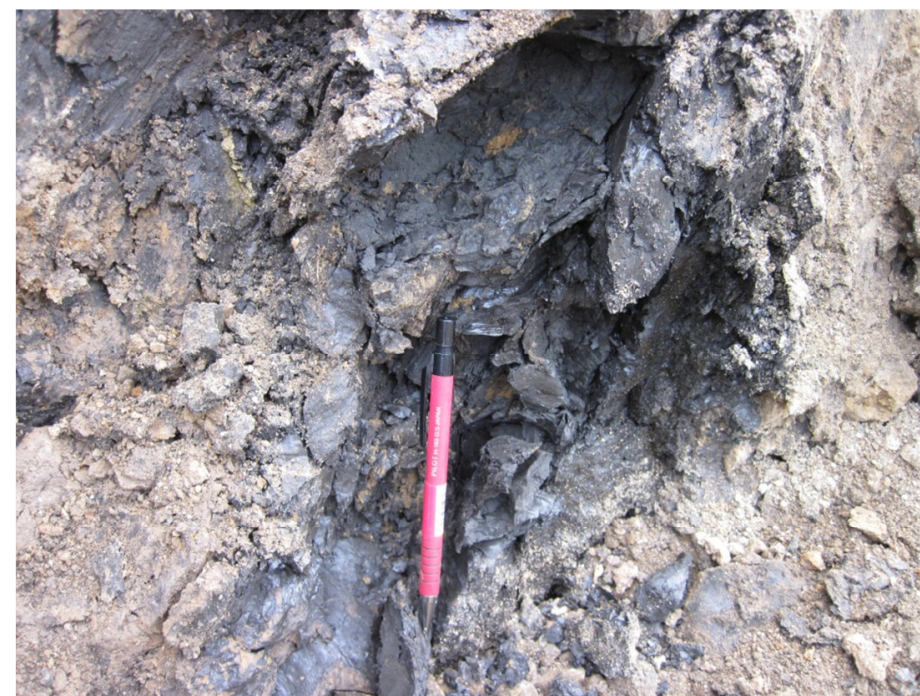

Gambar 7B. Batulempung hitam pada lokasi IC 08. 


\section{MAKALAH ILMIAH}

Singkapan yang dijumpai pada lokasi IC 09-IC 18 pada umumnya disusun oleh selang seling antara batugamping, batulempung, batupasir dan napal (Gambar 8). Batugamping berwarna abuabu hingga kuning kecoklatan, mengandung potongan koral masif, platy coral, foraminifera besar dan moluska.
Batugamping ini termasuk dalam batugamping packstone. Batulempung berwarna abu-abu gelap, gampingan dan menyerpih (Gambar 9). Perselingan antara batupasir, batulempung dan napal dengan tebal lapisan berkisar 5-15 cm. Pada lokasi ini diambil 4 conto batulempung (IC 10, IC 11, IC $12 \mathrm{E}$, IC 14) untuk analisis TOC.

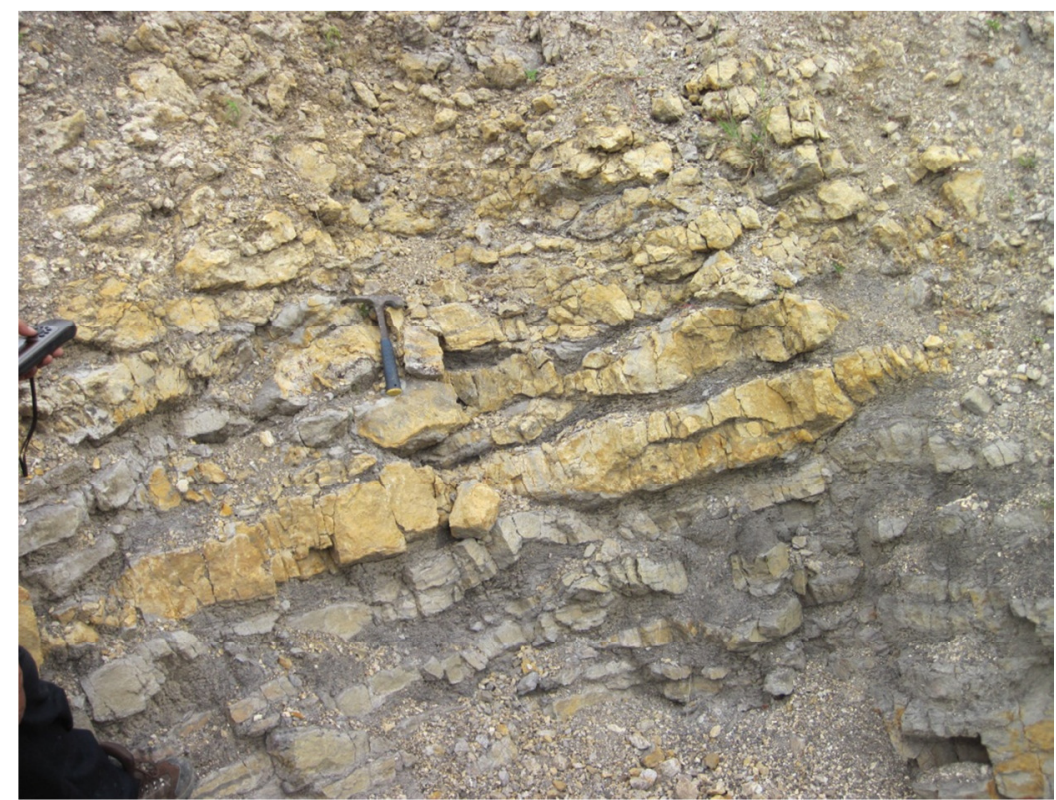

Gambar 8. Singkapan yang disusun oleh selang seling antara batugamping, batulempung, batupasir dan napal di lokasi IC 10.

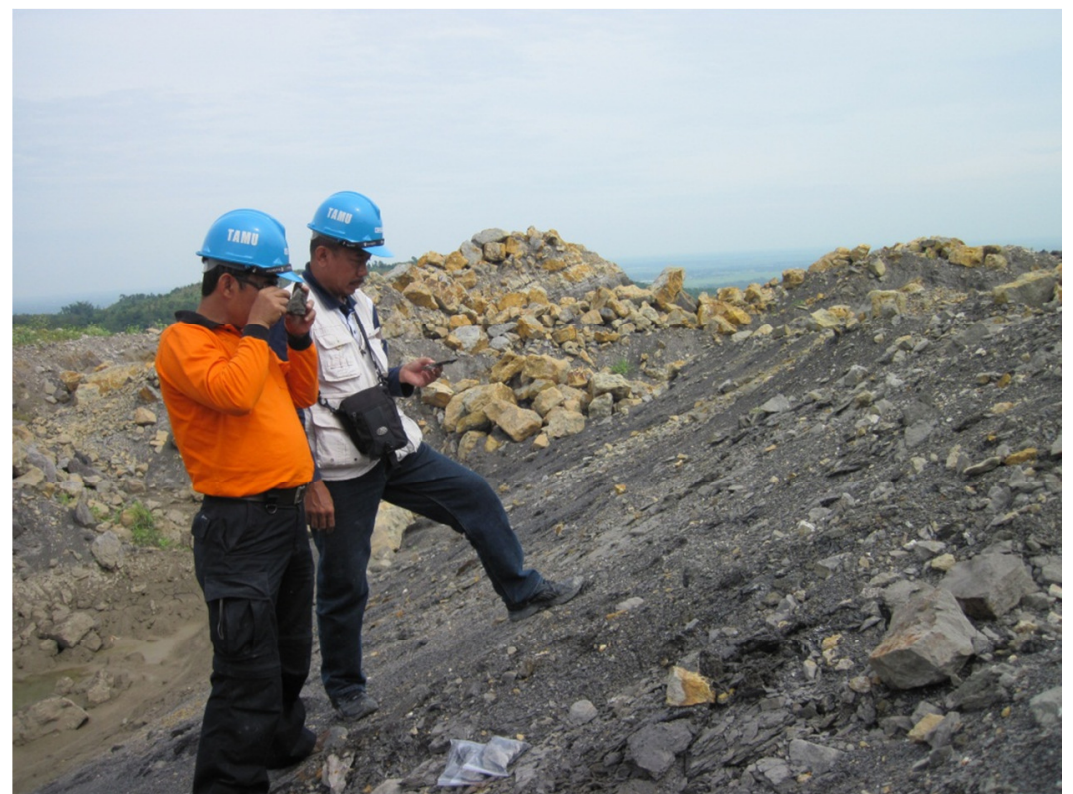

Gambar 9. Batulempung berwarna abu-abu gelap, gampingan dan menyerpih di lokasi IC 11. 


\section{MAKALAH ILMIAH}

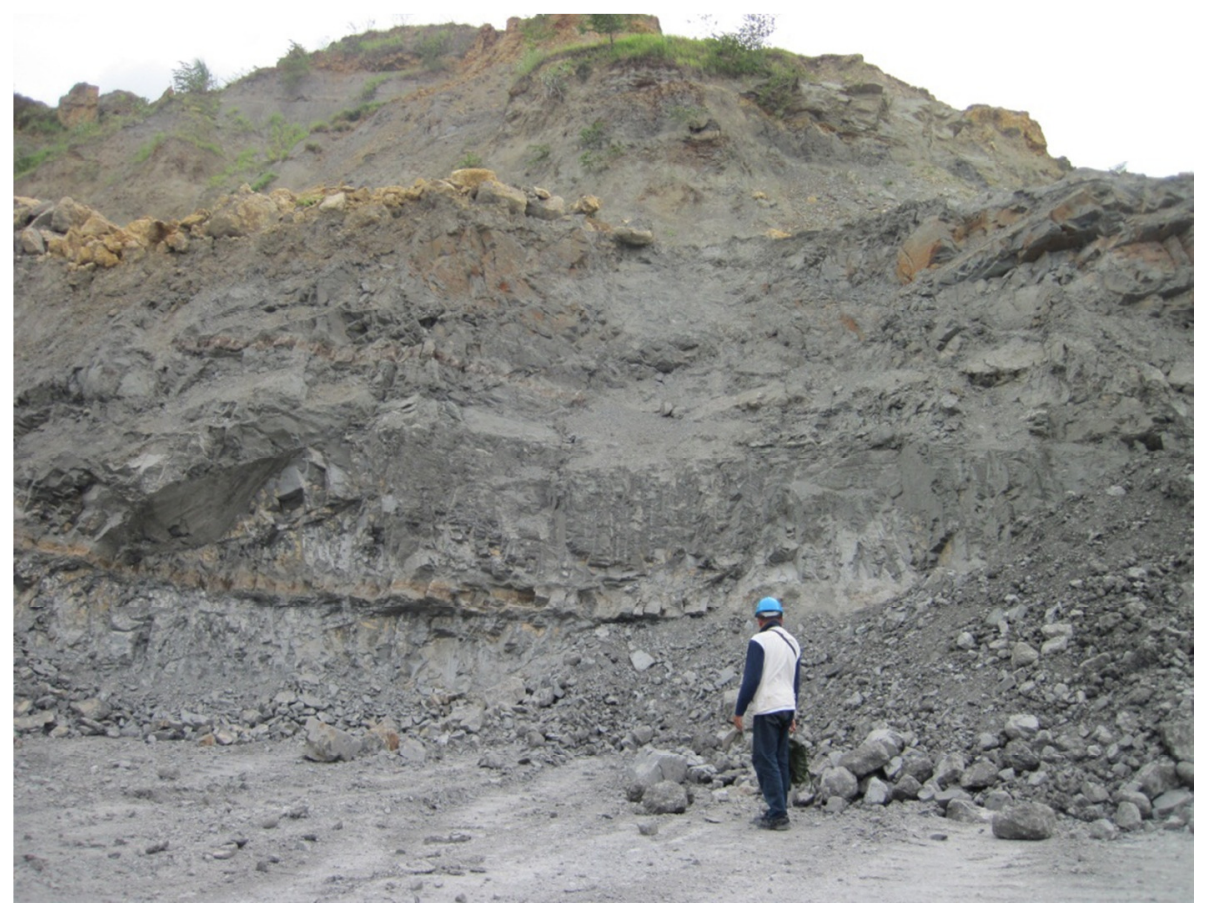

Gambar 10. Perselingan antara batugamping, batupasir dan batulempung di lokasi IC 26.

Lokasi IC 19-IC 30 terletak pada Quary C yang tersusun oleh perselingan antara batugamping, batupasir dan batulempung (Gambar 10). Batugamping packstone berwarna abu-abu hingga kuning kecoklatan, mengandung branching coral, platy coral, moluska dan foram besar dengan tebal lapisan $30-40 \mathrm{~cm}$. Batupasir, berwarna abu-abu dan kompak berlapis dengan tebal lapisan $10-30 \mathrm{~cm}$. Batulempung, berwarna abu - abu gelap dan menyerpih. Pada lokasi ini diambil 4 conto batulempung (IC $26 \mathrm{C}, \mathrm{IC} 27, \mathrm{IC} 28$, IC 34) untuk analisis TOC.

\section{ANALISIS GEOKIMIA}

Analisis geokimia dilakukan pada conto batulempung yang diambil dari Formasi Cibulakan, meliputi analisis TOC dan pirolisis Rock Eval. Analisis pirolisis Rock Eval dilakukan untuk conto yang mempunyai kandungan TOC $>0,5 \%$, dengan asumsi nilai tersebut merupakan nilai batas yang dapat menghasilkan hidrokarbon (Ronov, 1958, op. cit Katz, 1991). Dalam penelitian ini dilakukan analisis TOC sebanyak 17 conto dan analisis pirolisis Rock Eval sebanyak 9 conto.

\section{Hasil Analisis Kandungan Material Organik (TOC)}

Di daerah penelitian di analisis sebanyak 17 conto batulempung dan batulanau yang diambil dari Formasi Cibulakan. Berdasarkan hasil analisis TOC pada Formasi Cibulakan mempunyai kadar TOC berkisar 0,27-4,43\%. Angka tersebut menunjukkan batulempung dan batulanau di daerah tersebut berpotensi rendah hingga sangat baik membentuk hidrokarbon.

\section{Hasil Analisis Pirolisis Rock Eval.}

Analisis Pirolisis Rock Eval dilakukan pada conto yang mempunyai kandungan TOC $>0,50$ untuk mengetahui kandungan indeks produksi (PI), Indeks Hidrogen $(\mathrm{HI})$ dan temperatur maksimum pembentukan hidrokarbon dari kerogen. Di daerah penelitian dianalisis sebanyak 9 conto pada batulempung yang diambil dari Formasi Cibulakan. Hasil analisis dapat dilihat pada Tabel 2. 


\section{MAKALAH ILMIAH}

Tabel 1. Hasil Analisis TOC dari Formasi Cibulakan

\begin{tabular}{ccccc}
\hline No & No. Conto & Lokasi & Litologi & TOC (\%) \\
\hline 1 & B03 & Sungai Penawaran & Batulempung & 0,42 \\
2 & IC 01 & Area Pabrik Semen & Batulempung & 3,32 \\
3 & IC 02 & Area Pabrik Semen & Batulempung & 2,08 \\
4 & IC 03 & Area Pabrik Semen & Batulempung & 1,86 \\
5 & IC 04 & Area Pabrik Semen & Batulempung & 2,51 \\
6 & IC 05 & Area Pabrik Semen & Batulempung & 4,43 \\
7 & IC 07 & Area Pabrik Semen & Batulempung & 0,46 \\
8 & IC 08 & Area Pabrik Semen & Batulempung & 1,91 \\
9 & IC 11 & Area Pabrik Semen & Batulanau & 0,32 \\
10 & IC 12 E & Area Pabrik Semen & Batulempung & 0,31 \\
11 & IC 14 & Area Pabrik Semen & Batulanau & 1,36 \\
12 & IC 26 D & Area Pabrik Semen & Batulempung & 0,82 \\
13 & IC 27 & Area Pabrik Semen & Batulempung & 1,26 \\
14 & IC 28 & Area Pabrik Semen & Batulanau & 0,40 \\
15 & IC 34 & Area Pabrik Semen & Batulanau & 3,63 \\
16 & PB 01 & Sungai Penawaran & Batulanau & 0,47 \\
17 & PB 05 & Sungai Penawaran & Batulanau & 0,27 \\
\hline
\end{tabular}

Tabel 2. Hasil Analisis Pirolisis Rock Eval dari conto batulempung

\begin{tabular}{|c|c|c|c|c|c|c|c|c|c|c|}
\hline \multirow{2}{*}{ No } & \multirow{2}{*}{ Sampel } & \multirow{2}{*}{$\begin{array}{c}\text { TOC } \\
(\%)\end{array}$} & S1 & S2 & S3 & PY & \multirow{2}{*}{ PI } & \multirow{2}{*}{$\begin{array}{l}\mathrm{T}_{\max } \\
\left({ }^{\circ} \mathrm{C}\right)\end{array}$} & \multirow{2}{*}{$\mathrm{HI}$} & \multirow{2}{*}{ OI } \\
\hline & & & \multicolumn{4}{|c|}{$M g / g$} & & & & \\
\hline 1 & IC $01 \mathrm{~A}$ & 3,32 & 0,14 & 0,11 & 0,05 & 0,25 & 0,56 & 539 & 3 & 2 \\
\hline 2 & IC 02 A & 2,08 & 0,08 & 0,38 & 0,08 & 0,46 & 0,17 & 557 & 18 & 4 \\
\hline 3 & IC 03 & 1,86 & 0,13 & 0,37 & 0,09 & 0,50 & 0,26 & 529 & 20 & 5 \\
\hline 4 & IC 04 & 2,51 & 6,18 & 2,85 & 0,49 & 9,03 & 0,68 & 331 & 114 & 20 \\
\hline 5 & IC 05 & 4,43 & 10,08 & 14,98 & 0,50 & 25,06 & 0,40 & 362 & 338 & 11 \\
\hline 6 & IC 08 & 1,91 & 0,13 & 0,46 & 0,14 & 0,59 & 0,22 & 529 & 24 & 7 \\
\hline 7 & IC 14 & 1,36 & 0,07 & 0,09 & 0,11 & 0,16 & 0,44 & 533 & 7 & 8 \\
\hline 8 & IC 27 & 1,26 & 0,66 & 0,09 & 0,21 & 0,15 & 0,40 & 362 & 7 & 17 \\
\hline 9 & IC 34 & 3,63 & 2,28 & 3,27 & 0,23 & 0,41 & 5,55 & 445 & 90 & 6 \\
\hline
\end{tabular}

\section{PEMBAHASAN}

Kisaran nilai Indeks Hidrogen (HI) conto batulempung Formasi Cibulakan di daerah penelitian berkisar antara 3-338 mg HC/TOC (Tabel 1). Berdasarkan klasifikasi fasies Jones (Jones, 1987) nilai HI pada batulempung Formasi Cibulakan dapat dikelompokkan menjadi 3 fasies organik. Kelompok pertama adalah fasies organik $D$ yang mempunyai nilai $\mathrm{HI}$ sebesar 3-24 mg HC/TOC sebanyak 6 conto. Kelompok kedua adalah Fasies CD yang mempunyai nilai $\mathrm{HI}$ sebesar 90-114 mgHC/TOC sebanyak 2 conto. Kelompok ke 3 adalah fasies $\mathrm{BC}$ yang mempunyai $\mathrm{HI}$ $338 \mathrm{mg} \mathrm{HC} / \mathrm{TOC}$ sebanyak 1 conto. Nilai $\mathrm{HI}$ memberikan gambaran bahwa conto tersebut dapat menghasilkan minyak dalam kualitas sedang dan gas dalam kualitas rendah (Waples, 1985). 


\section{MAKALAH ILMIAH}

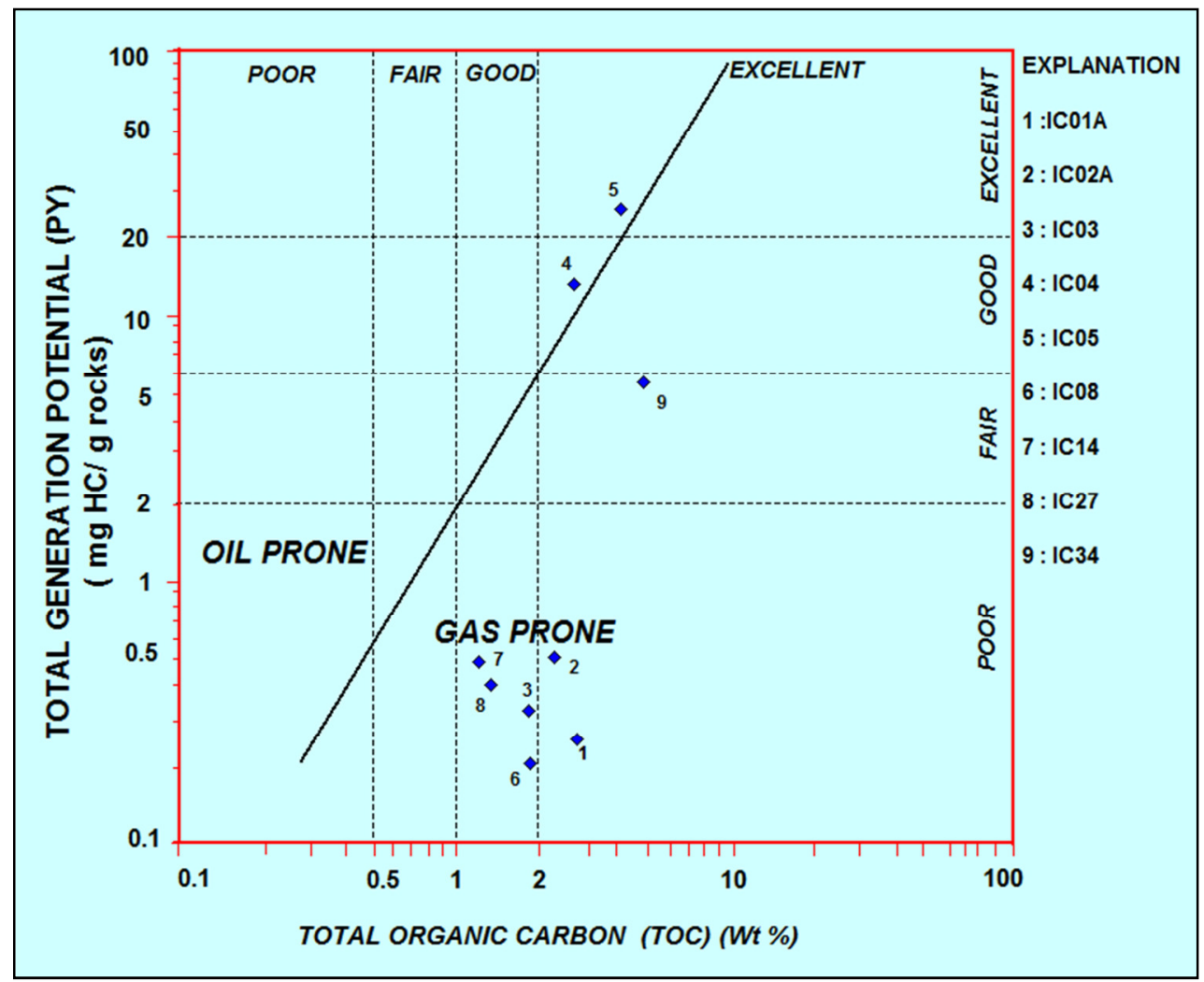

Gambar 10. Ploting semua conto pada diagram TOC terhadap Total Generation Potensial (PY).

Diagram TOC vs PY (Gambar 15) memperlihatkan potensi hidrokarbon di daerah penelitian yang ditunjukkan oleh tingkat kekayaan kandungan material organik (Rad, 1984). Satu conto batulempung Formasi Cibulakan yaitu IC 05 yang mempunyai nilai TOC $4,43 \%$ dan PY 25,06 mg HC/g menunjukkan kondisi material organik sangat baik. Conto IC 04 mempunyai nilai TOC sebesar $2,51 \%$ dan PY sebesar 9,03 mg HC/g menunjukkan kondisi material organik baik. Sedangkan 6 conto yang lain yaitu IC 01A, IC 02A, IC 03, IC 08, IC 14 dan IC 27 mempunyai nilai TOC sebesar 1, 26-3,30 dan PY sebesar 0,22-0,50 $\mathrm{mg} / \mathrm{g}$, menunjukkan kategori material organik rendah.

Diagram Hydrogen Index $(\mathrm{HI})$ vs $T_{\text {maks }}$ (Gambar 11) menunjukkan tipe kerogen dan tingkat kematangan termal daerah penelitian. Batulempung Formasi
Cibulakan yang mempunyai nilai $\mathrm{HI}$ berkisar antara 3-24 mg HC/TOC (IC 01A, IC 02A, IC 03, IC 08, IC 14) kerogennya termasuk dalam type III dengan nilai $\mathrm{T}_{\text {maks }}$ sebesar $529-557{ }^{\circ} \mathrm{C}$ menunjukkan tingkat kematangan termal kategori pasca matang. conto IC 34 mempunyai nilai HI sebesar 90 mg HC/TOC, kerogennya termasuk dalam type III dengan nilai $T_{\text {maks }}$ sebesar $445{ }^{\circ} \mathrm{C}$ menunjukkan tingkat kematangan termal kategori matang. Sedangkan untuk 2 conto yang lain yaitu IC 4 dan IC 27 mempunyai nilai $\mathrm{HI}$ sebesar $7-114 \mathrm{mg} \mathrm{HC} / \mathrm{TOC}$, dengan kerogen tipe III, tingkat kematangan sebesar $331-362{ }^{\circ} \mathrm{C}$, dikategorikan belum matang. Pada conto IC 05 mempunyai $\mathrm{HI}$ sebesar $338 \mathrm{mg}$ $\mathrm{HC} / \mathrm{TOC}$ termasuk dalam type kerogen II dengan nilai $\mathrm{T}$ maks sebesar $362{ }^{\circ} \mathrm{C}$ yang menunjukkan tingkat kematangan thermal belum matang. 


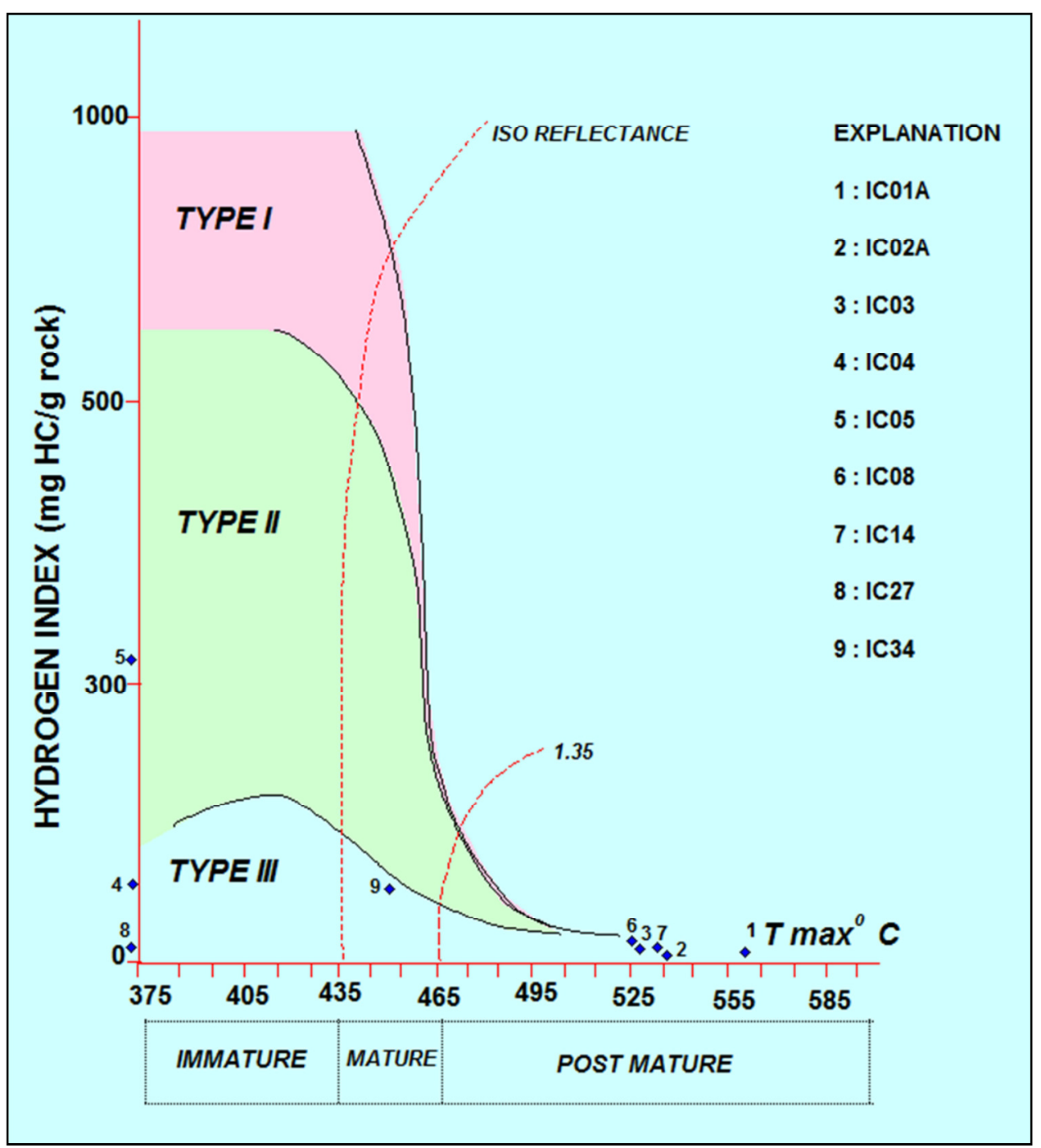

Gambar 11. Ploting semua conto pada diagram $T_{\max }$ terhadap indeks hidrogen yang memperlihatkan tipe kerogen dan tingkat kematangan. (Espitalié, J., 1984, op.cit Mukhopadhyay, 1995)

Kualitas batuan sumber conto batulempung Formasi Cibulakan daerah penelitian berdasarkan nilai TOC pada dua conto yaitu IC 04 dan IC 05 sebesar 2,51 $\%-4,43 \%$ dan PY sebesar 9,03-25,05 mg $\mathrm{HC} / \mathrm{g}$, termasuk dalam kategori oil prone (Rad, 1984). Sedangkan 7 conto yang lain mempunyai nilai TOC sebesar 1,91-3,36 \% dan PY sebesar 0,22-0,50 $\mathrm{mg} \mathrm{HC/g}$, termasuk dalam kategori gas prone. Sementara menurut Waples (1985), sebanyak 6 conto nilai $\mathrm{HI}<150 \mathrm{mg}$ HC/TOC dapat menghasilkan gas dalam kualitas kecil, 2 conto mempunyai nilai 90$114 \mathrm{mg} \mathrm{HC} / \mathrm{TOC}$ dapat menghasilkan gas dan minyak dalam kualitas kecil dan 1 conto mempunyai $\mathrm{HI}$ sebesar $338 \mathrm{mg}$
$\mathrm{HC} / \mathrm{TOC}$ dapat menghasilkan minyak dalam kualitas sedang.

\section{KESIMPULAN}

Hasil analisis geokimia 9 conto batulempung dan batulanau Formasi Cibulakan di daerah penelitian menunjukkan TOC sebesar 0,27-4,4\%. Kondisi ini mengindikasikan bahwa pada umumnya conto tersebut mempunyai potensi rendah hingga sangat baik untuk membentuk hidrokarbon. Kisaran $\mathrm{T}$ max conto batulempung dan batulanau daerah penelitian adalah $422-432{ }^{\circ} \mathrm{C}$. Dari hasil tersebut menunjukkan 3 conto dinyatakan belum matang dengan nilai $T$ max 331 $557{ }^{\circ} \mathrm{C}$. Sedang 6 conto yang lain 


\section{MAKALAH ILMIAH}

mempunyai nilai T Max sebesar 445 - 557 ${ }^{\circ} \mathrm{C}$, dinyatakan matang hingga pasca matang. Satu conto mempunyai Tmax 467 ${ }^{\circ} \mathrm{C}$, termasuk kategori pasca matang. Nilai Hidrogen Indeks (HI) Formasi Cibulakan berkisar antara 3-338 mg HC/TOC mg HC/TOC dapat dibedakan menjadi Fasies organik. Fasies yang pertama adalah organik $D$ yang mempunyai nilai $\mathrm{HI}$ sebesar 3-24 mg HC/TOC sebanyak 6 conto. Fasies organik kedua adalah Fasies $\mathrm{CD}$ yang mempunyai nilai $\mathrm{HI}$ sebesar $90-$ $114 \mathrm{mgHC} / \mathrm{TOC}$ sebanyak 2 conto.

Fasies organik ke tiga adalah fasies $\mathrm{BC}$ yang mempunyai $\mathrm{HI} 338 \mathrm{mg} \mathrm{HC} / \mathrm{TOC}$ sebanyak 1 conto. Karakteristik batuan sumber hidrokarbon Formasi Cibulakan di daerah penelitian berdasarkan diagram TOC vs PY menunjukkan kategori kekayaan material organik rendah hingga sangat baik. Diagram Indeks Hidrogen ( $\mathrm{HI})$ vs Tmax menunjukkan kerogen type III dan II. Kualitas conto batulempung Formasi Cibulakan di daerah penelitian berdasarkan nilai $\mathrm{HI}$ termasuk dalam kategori gas prone dan oil prone, dapat menghasilkan minyak dalam kualitas sedang dan gas dalam kualitas rendah.

\section{UCAPAN TERIMA KASIH}

Pada kesempatan ini penulis mengucapkan terima kasih pada Kepala Puslit geoteknologi LIPI yang telah memberikan kesempatan pada penulis untuk menerbitkan tulisan ini. Terima kasih juga kepada P2K Puslit Geoteknologi LIPI Tahun Anggaran 2013 atas kesempatan kepada kami melakukan penelitian. Juga kepada rekan-rekan peneliti kami ucapkan terima kasih atas diskusinya.

\section{DAFTAR PUSTAKA}

Djuri, 1995, Peta Geologi Lembar Arjawinangun , Jawa, skala 1 : 100.000. Pusat Penelitian dan Pengembangan Geologi.

Einsele, G., 2000, Sedimentary Basins : Evolution, Facies, and Sediment Budget, Springerverlag, Berlin, $2^{\text {nd }}$, p. $706-722$.

Jones, R. W., 1987, Organic Facies, In : Brooks J. And Welte, D.H. (eds), Advances in Petroleum Geochemistry, 2. Academic Press, London, h 1-90.

Katz, B. J., 1991, Organic geochemistry and basin evaluation, Bahan kursus geokimia minyak bumi, ITB, Januari.

Mukhopadhyay, P. K., Wade J.A., Gruge M. A., 1995, Organic facies and maturation of Jurassic/ cretaceous rocks, and possible oil-source rock correlation based on pyrolysis of asphaltenes, Scotian Basin Canada, Org. Geochem., Vol. 22, No.1, pp. 85- 104.

Panggabean, H., and Heryanto, R., 2009. An appraisal for the petroleum source rocks on oil seep and rock samples of the Tertiary Seblat and Lemau Formations, Bengkulu Basin. Jurnal Geologi Indonesia, Vol.4 No. 1 Maret 2009: 43-55.

Praptisih, Kamtono, Joko Trisuksmono dan Adde Tatang, 2013, Penelitian batuan induk hidrokarbon daerah Cirebon, Jawa Barat. Laporan Penelitian Program dan Pengembangan IPTEK Tahun Anggaran 2013. Puslit Geoteknologi LIPI Bandung.

Pringgoprawiro, H., Suryo Suwito, P., Roskamil, 1977, The Kromong carbonate rocks and their relationship with the Cibulakan and Parigi Formation. Paper presented at the $6^{\text {th }}$ Ann. Indonesian Petroleum Association, Jakarta.

Rad, F.K., 1984, Quick Look Source Rock Evaluation By Pirolysis Technique. Proceeding 13 th Annual Convention Indonesian Petroleum Association, h. 113-124.

Waples D.W.,1985. Geochemistry in Petroleum Exploration, International Human Resources Development Co., Boston, $232 \mathrm{~h}$. 